\title{
MASQUERADE GAMES IN THE PERNIK REGION OF BULGARIA: PRESERVING AND PROMOTING INTANGIBLE CULTURAL HERITAGE
}

\author{
Milena Lyubenova \\ Assistant Professor at the Institute of Ethnology and Folklore Studies with Eth- \\ nographic Museum, Bulgarian Academy of Sciences Institute of Ethnology and \\ Folklore Studies with Ethnographic Museum, Bulgarian Academy of Sciences \\ e-mail: milena.lyubenova@iefem.bas.bg
}

\begin{abstract}
The focus of this text is the masquerade tradition in central-west Bulgaria and activities related to its safeguarding and promotion. The essence of the survakar games in the Pernik Region is described, as well as its significance in traditional culture and its contemporary manifestations. The games with masks in the region are performed on the Surva feast day (14 January; also St. Basil's Day according to the Julian calendar). The text notes the importance of the custom in the local community's traditional culture. The main characters in the survakar groups, which are typical of both the past and the present, are presented, as are some new phenomena related to the feast. The tendencies in the context of the dynamics and events of the twentieth century are outlined, thanks to which the masquerade tradition has maintained its vitality until the present day. Some processes that have threatened the vitality of these masquerade games in the past are considered. Various local activities related to the safeguarding of the tradition are presented. The role of the community is important for the transmission of cultural practice to future generations, as is the role of local cultural institutions and organizations in preserving the tradition. Some ways of popular-
\end{abstract}


izing the local heritage and the joint work of the main actors engaged in safeguarding the region's intangible cultural heritage today are emphasized.

Keywords: masquerade games, surva (surova), intangible cultural heritage, preservation, promotion.

\section{Introduction}

In the context of processes for preserving intangible cultural heritage, communities have a main role in taking care of their own cultural heritage. According to the Convention for the Safeguarding of the Intangible Cultural Heritage (Convention 2003), ${ }^{1}$ it is local communities that have the central role in both identifying intangible cultural heritage and implementing proposed safeguarding measures, as well as in the maintenance and transmission of this heritage and communities' active involvement in its management (Article 15). At the same time, each state is needs to adopt a general policy aimed at promoting the function of its intangible cultural heritage in society; integrating the safeguarding of such heritage into planning programmes; designating or establishing one or more competent bodies for the safeguarding of the intangible cultural heritage that is present in its territory; fostering scientific, technical and artistic studies, as well as research methodologies, with a view to the effective safeguarding of intangible cultural heritage; fostering the creation or strengthening of institutions for training in the management of intangible cultural heritage; and establishing institutions to document intangible cultural heritage and to facilitate access to them. (Article 13). All these guidelines in Convention 2003 presuppose very close cooperation between the various actors working in the field of preserving intangible cultural heritage - communities, groups and individuals, national and local institutions, and both governmental and non-governmental organizations.

The focus of this text is how the masquerade tradition in central-west Bulgaria is being preserved and more specifically how cooperation between communities and experts in the safeguarding and promotion of the tradition of masquerade games in the Pernik region is being carried out. The text traces the interactions between communities, experts and institutions over a period of more than fifty years, which includes the periods both before and after Bulgaria’s ratification of Convention 2003 in 2006. 


\section{Masquerade games in Pernik Region}

The tradition of masquerade games ${ }^{2}$ in central-west Bulgaria is bound up with the winter ritual cycle and is a significant element of the intangible cultural heritage of scores of villages in Pernik District. This ancient tradition, still alive at the present day, occupies an important place in the local population's festive calendar, and the local region in which the masquerade remains a cultural practice comprises more than fifty settlements.

The masquerade games are performed on 14 January (St. Basil's Day according to the Julian calendar), the ritual starting already on the eve of the holiday. In the old style calendar, this is New Year's Day, called by local communities Surva, Surova or Sirova, while the participants are called survakari, survashkarye, sirviskarye, mechkarye or startsi. Preparation for the games begins as early as late autumn, when the work in the fields draws to an end. Then people gather skins, dried birds' feathers and wings, and look for bells. Before the holiday itself, the participants meet together to allocate the different characters and elect their leader. Until the beginning of the twentieth century, only young unmarried men from the local community disguised themselves, because the custom had the function of an initiation ceremony, as well as being connected with their future marriages (Manova 1977; Kraev 2003). Today men of all ages, as well as women and children also put on masks. In some villages, there are numerous children's groups, including some of the characters typifying the groups of adults.

The masquerade group represents a wedding procession with the following characters- 'bride,' 'bridegroom, 'father-in-law', 'mother-in-law', 'best man', 'woman witness', 'priest', 'sexton', 'bear with bear keeper.' Other characters are the group's leader (bolyubasha) and the 'gypsies' (Roma), as well as some modern ones like 'doctor,' 'nurse', 'policeman', etc. (Figs. 1-2). Those who are connected with the idea of a wedding are dressed in traditional costumes, typical for the region. The survakars who wear masks are dressed in hides, the fur inside out, and they wear bells on their waists. After the 1930s, they start to make some of the costumes from worn-out clothes, cut to rags. Nowadays, such costumes are made from different bands of material, cut from pieces of cloth. The masks for the head bear the local designation lik/litsi (effigy/effigies). They are made of wood, stuffed parts of domestic animals, leather, horns, tails, birds' wings and feathers. The masks are zoomorphic and more rarely anthropomorphic (Figs. 3-4). 


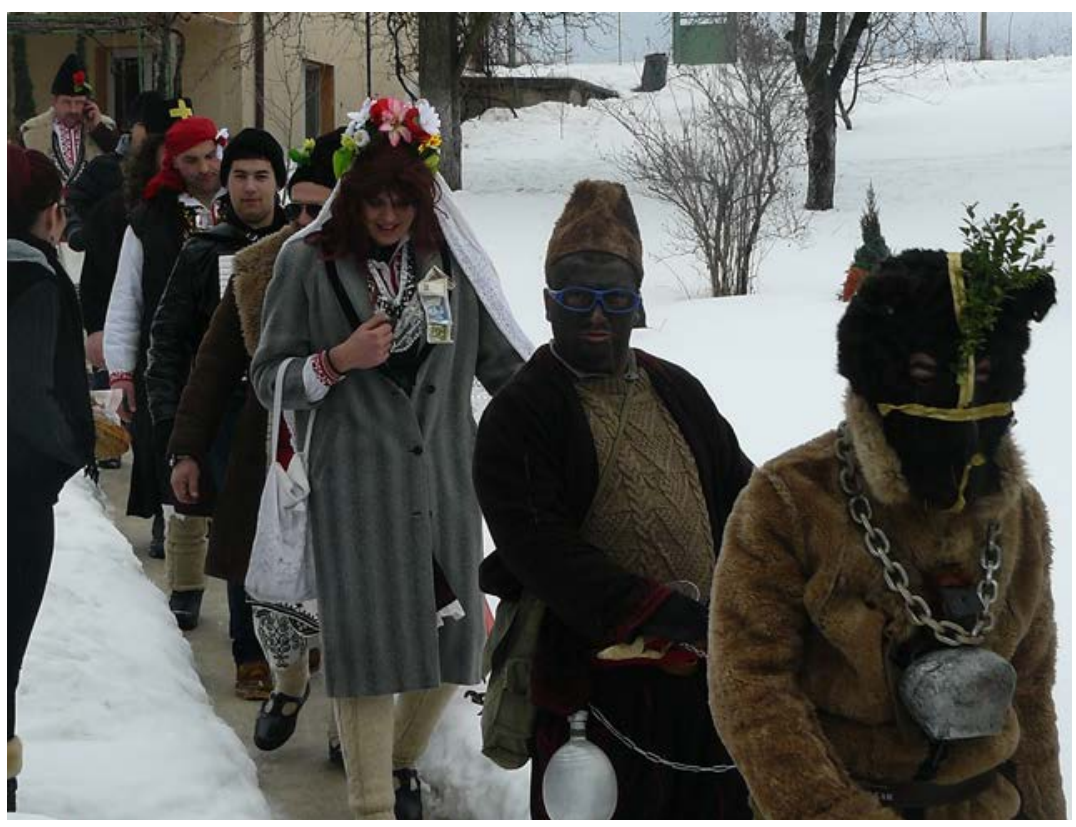

Figure 1. Wedding procession and 'bear with a bear keeper' from Lyulin village, Pernik Region. Fhoto: Milena Lyubenova, 2017. (Archive IEFSEM - BAS: FtAIF № 1575, arch. unit 180).

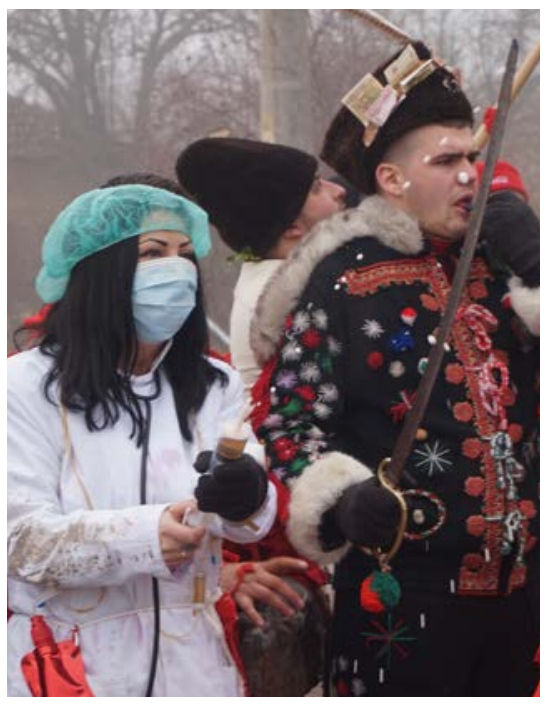

Figure 2. 'Nurse' and Leader of the group from Kosharevo village. Fhoto: Milena Lyubenova, 2020. (Archive IEFSEM - BAS: FtAIF №1837, arch. unit 290). 


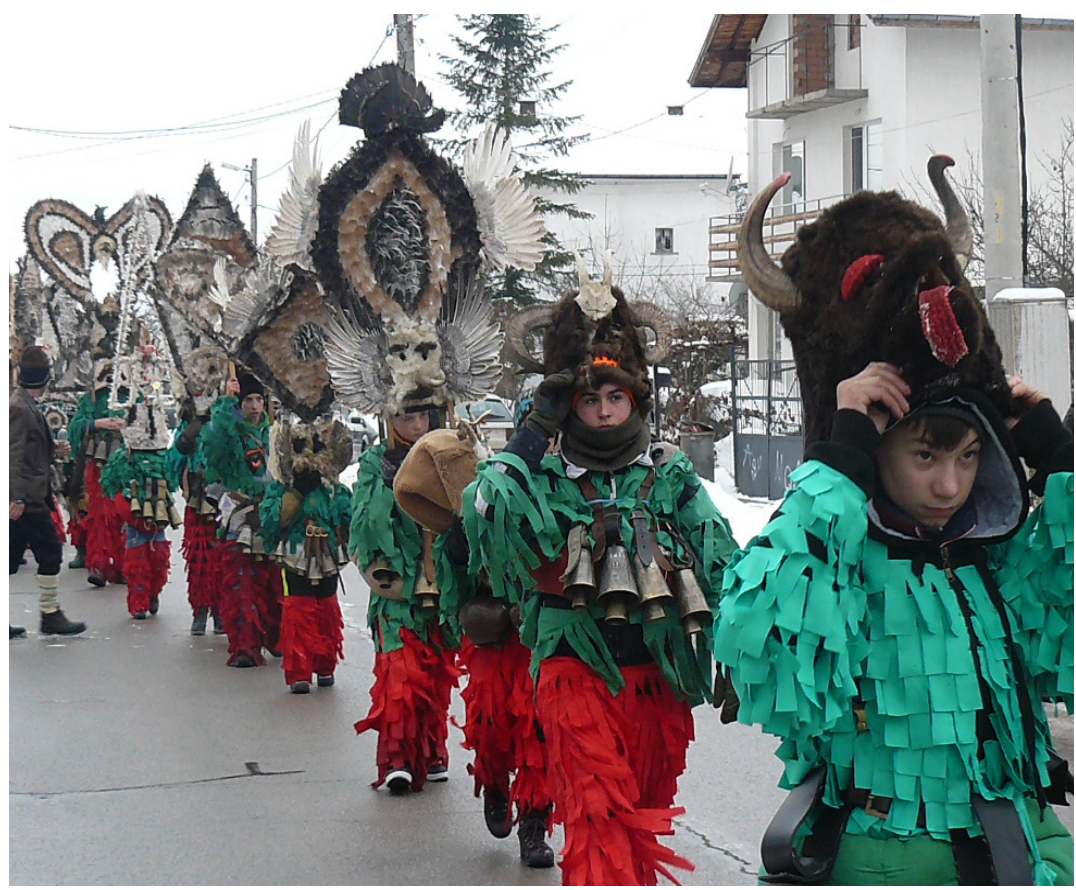

Figure 3. Survakar group from Divotino village. Fhoto: Milena Lyubenova, 2019. (Archive IEFSEM - BAS: FtAIF No.1751, arch. unit 320). 
In the past, late in the evening of 14 January, the survakars gathered at a house, disguised and already masked, to start visiting the households in the village. Frequently they first visited a neighbouring village before going around their own. Today, the holiday is on both 13 and 14 January. In the evening of 13 January, the survakars go to the centre of the settlement, light fires, dance around them, jest with the crowd, visit neighbouring villages, welcome other masquerade groups, and, with everyone else, take part in the chain dance or horo, enjoying the fun. Early in the morning of 14 January, the masked characters gather again to walk around the village. As a rule, they visit every home, and people interpret this as a wish for good health and well-being. In every house, the 'priest' weds the 'newly-weds', 'the bear mauls people for good health' and everyone else dances noisily and joyously around in the yard. The hosts anticipate them eagerly and with love, welcome them with traditional food, treat them and give them money, meat, fruit and drinks. The whole population of the village takes part in the holiday, which makes the custom extremely lively and dynamic in our days. Every Surva group has between fifty and a hundred participants, so that on the feast of 13 and 14 January those wearing masks in Pernik region grow to several thousand. In spite of the social and political changes after the middle of the twentieth century and, notwithstanding the country's intensive industrialization and modernization, with their impact on practising the elements of traditional culture in their natural environment, the masquerade tradition in the Pernik region has proved to be resistant and to this very day is being transmitted to future generations.

After 1944, ${ }^{3}$ there were some towards administrative restrictions being placed on those practicing Surva games (Bokova 2010), but no permanent prohibition was introduced. Later during socialism, some attempts were made to change the date of the masquerade games, the authorities wishing them to be preformed on a rest day (Saturday or Sunday). This was to try and avoid people's mass absence from work when the holiday coincided with a workday. However, those attempts were unsuccessful due to resistance from the participants in the survakar groups. ${ }^{4}$

After the mid-1950s, the increased industrialization of the country and the wave of migration from villages to towns put the practice of the masquerades at risk. In that period, became one of the main industrial centres in Bulgaria, ${ }^{5}$ which accelerated the movement of the region's inhabitants into the town. This 
impacted on the survakar games in some of the villages, where the custom gradually started dying out.

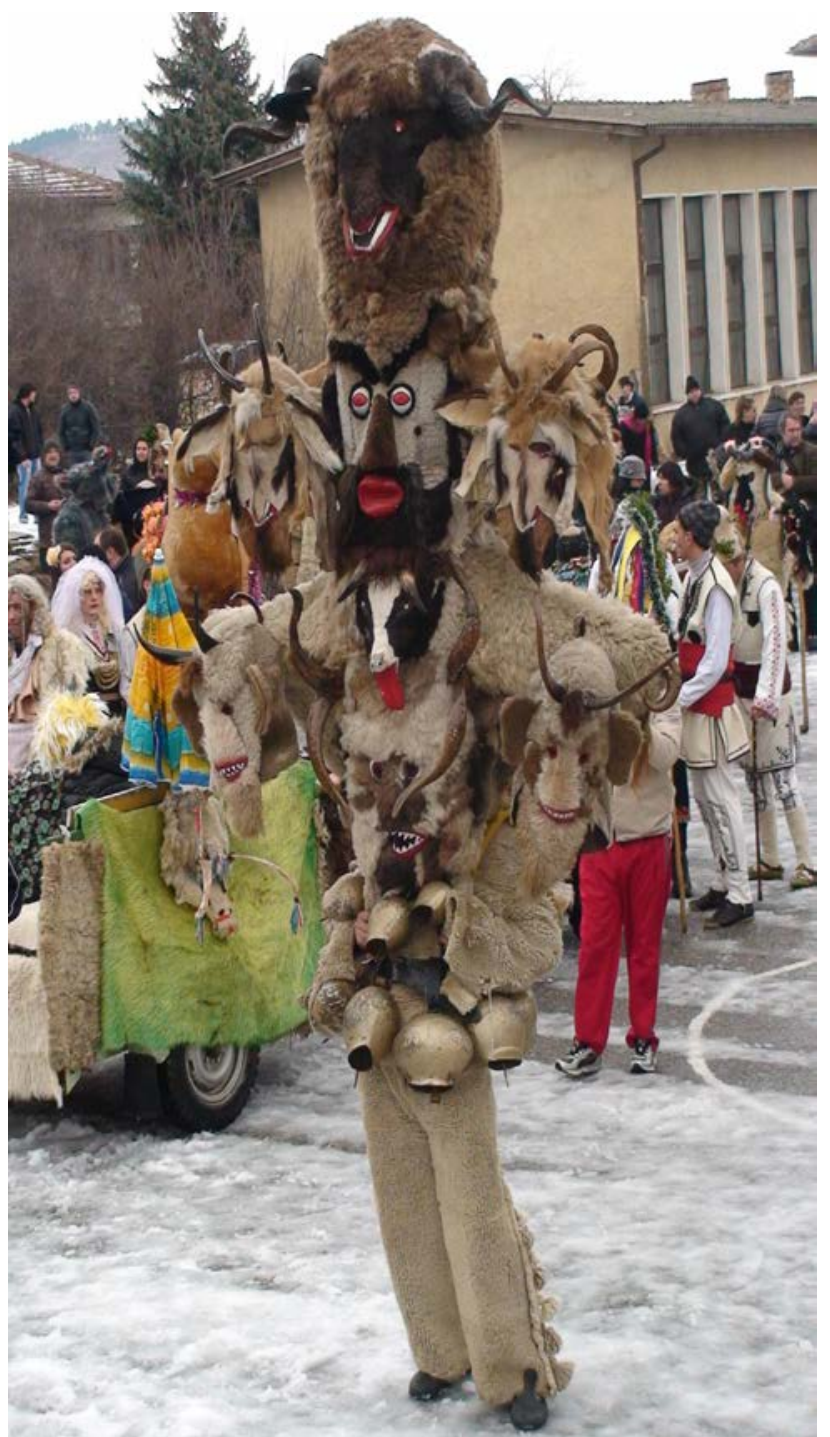

Figure 4. Survakar from Yardzhilovtsi village. Fhoto: Milena Lyubenova, 2013. Archive IEFSEM - BAS: FtAIF No.1360, arch. unit 107). 


\section{The Festival of the Masquerade Games in Pernik}

Based on what remained of the living tradition, in 1966 a festival of masquerade games was established in Pernik. This was the initiative of Yordan Nikolov, a choreographer and folklorist, and also an inspector in the Culture and Art Department of the Pernik District People's Council (Georgiev 2017). The organization of the festival is related to the country's cultural policy at that time, which was directed at investigating and restoring old traditional customs, which start to be presented on the stages of folk festivals and feasts on a mass scale. ${ }^{6}$ As a result an urban holiday was introduced in Pernik, where the preserved survakar tradition from the region's settlements was presented to the public at large, together with the masquerade groups that had been invited from some other parts of the country (Figs. 5-7). After the 1960s, the activities related to safeguarding and popularizing the masquerade games in the Pernik region become an important part of the work of experts in the sphere of culture. In the following decades, there was continual research and cooperation between these specialists and the communities that still practiced the masquerade tradition.

As already stressed, this is a period of the active migration of the population of local villages to the town of Pernik. According to the local experts, an important factor in maintaining the survakar games as a living practice in the villages is considered to have been the National Festival of the Survakars and Kukers, organized in Pernik in 1966 (Manova 2012: 15-16). Over the years it won recognition as a significant cultural event in Pernik Municipality, and from 1985 acquired the statute of an international event in the form of an International Festival of the Masquerade Games - 'Surva.' In that same period of time of over fifty years, the interactions between local communities and cultural experts was a significant aspect of the region's cultural policy. Its aim, on the one hand, was to preserve the vitality of the local cultural tradition in the villages, while on the other hand developing the festival as a cultural event in Pernik town, at the same time giving it national and later international importance.

The International Festival of the Masquerade Games in Pernik has played a strong role in popularizing the masquerade tradition both in the country and abroad. In the course of time, its scope was broadened, and both its participants and its visitors increased in number. At present, the masquerade groups that part in the festival from Bulgaria and from all over the world number more than a hundred, and those in masks number over five thousand. 


\section{Masquerade Games in The Pernik Region of Bulgaria}

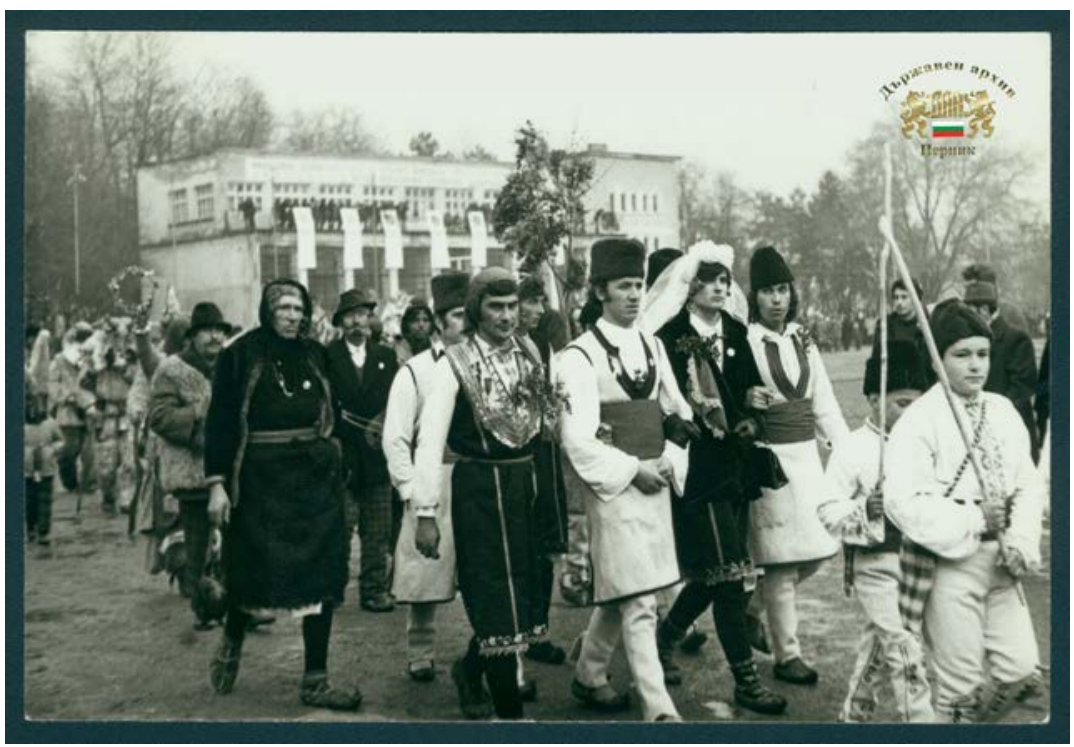

Figure 5. National Festival of Kukers and Survakars - Pernik 1977. Survakar group from Selishten dol village (State Archives - Pernik: Fond. 1134, inventory 1, arch. unit 81, page 2).

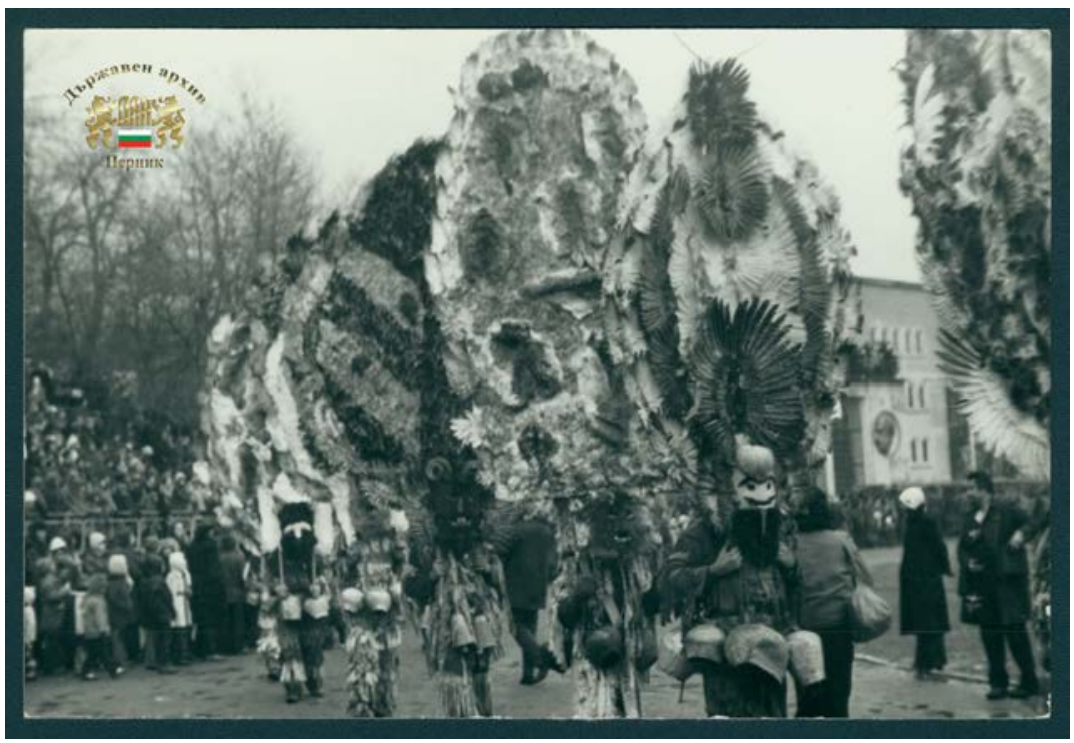

Figure 6. National Festival of Kukers and Survakars - Pernik 1977. Survakar group from Kosharevo village (State Archives - Pernik: Fond. 1134, inventory 1, arch. unit 78, page 3). 


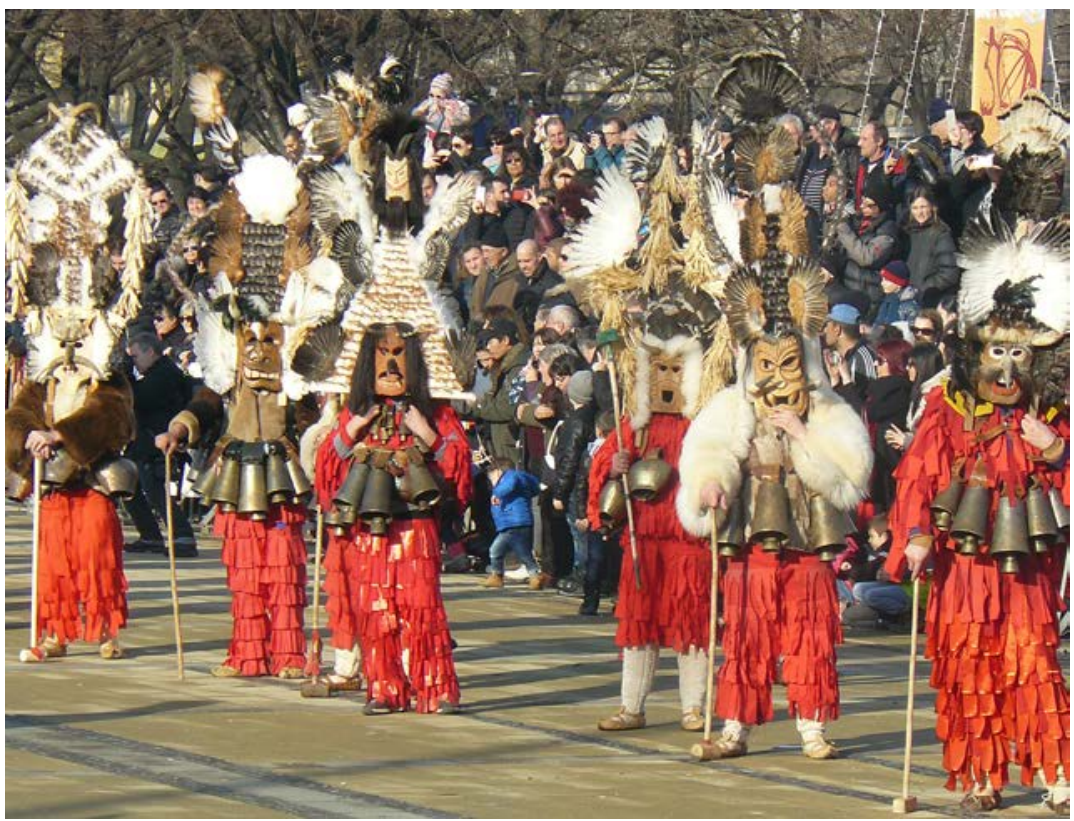

Figure 7. International Festival of Masquerade Games 'Surva' - Pernik 2016. Fhoto: Milena Lyubenova, 2016. (Archive IEFSEM - BAS: FtAIF №1517, arch. unit 337).

\section{Safeguarding intangible cultural heritage at the present day}

No doubt the experience acquired in these decades contributes to the joint work between communities and experts in activities related to applying to UNESCO Convention for the Safeguarding of Intangible Cultural Heritage being continued. As a result of this active work, in 2012 Pernik prepared to nominate the survakar games for the National System of 'Living Human Treasures - Bulgaria." The nomination includes 31 villages in Pernik District that are the bearers of the masquerade tradition and that have given their preliminary informed consent to take part in the National System. As a result, the cultural element is selected first regionally and then nationally, being inscribed in the National Representative List of elements of intangible cultural heritage in the same year. ${ }^{9}$

The initiative to include the masquerade games from the whole region in a single nomination and draw up a dossier on the 'Surova Folk Festival in the Pernik Region' was the outcome of active cooperation between local communi- 
ties and local experts, in which respect the role of the specialists was of special importance. The Regional Museum of History - Pernik drew the dossier up with the assistance of experts from the Regional Expert-Consulting and Information Centre - Pernik, the 'Culture' Department of Pernik Municipality and representatives of the culture centres or chitalishta ${ }^{10}$ in the villages of Pernik District. The participation of experts in preparing the nomination makes it possible to involve scores of villages in Pernik District and results in inscribing the custom in the National List of Elements of Intangible Cultural Heritage. At present, of all the nominations that took part in the National System, this is still the only one in Bulgaria representing an element that is typical for a whole region of the country.

In 2015, the masquerade tradition of Pernik region was also inscribed in UNESCO's Representative List of the Intangible Cultural Heritage of Humanity. ${ }^{11}$ Again, cooperation between local communities and local experts was of decisive importance, as was the joint work of experts both locally and nationally. For this nomination also increased the number of the settlements that gave their consent to their inclusion, a total of 41 survakar groups.

The active work of safeguarding the masquerade tradition in the Pernik region continued in the years that followed inscription of the element in the UNESCO Representative List. According to the Operational Directives for the Implementation of Convention 2003, non-governmental organizations (NGO), experts, centres of expertise and research institutes play a decisive role in safeguarding intangible cultural heritage. In the third chapter of the Directives, it is pointed out that the States Parties should guarantee the participation of the communities that are the bearers of the intangible cultural heritage, and should involve civil society in the implementation of the Convention both nationally and internationally. ${ }^{12}$ Nationally, in their safeguarding endeavours, the States Parties should encourage the participation of non-governmental organizations, especially in identifying and defining intangible cultural heritage, because these organizations are most often in the best position to work directly with local communities. ${ }^{13}$

The different actors involved in safeguarding intangible cultural heritage locally and nationally have their own role in the process (Ivanova 2016: 73-81; Stanoeva 2016: 179-92; Nalbantyan-Hacheryan 2019). As already emphasized, the role of the communities who are involved in safeguarding their own cultural heritage is very significant, indeed essential. In actual fact, the real preserva- 
tion of intangible cultural heritage goes on where it is continually practised (Stanoeva 2016: 181). Besides, an important factor in these processes is the involvement of both state institutions (national, regional and local) and nongovernmental organizations. The civil sector structures also have a significant role and can cooperate with the state, the local authority, the communities and the experts in all the aspects regarding the safeguarding of intangible cultural heritage. ${ }^{14}$ Most of those organizations work on the project principle, but look for sustainability in their activities namely in the interaction with state institutions, with scientific institutes and with the bearers of intangible cultural values (Nalbantyan-Hacheryan 2018: 26).

Until Surva was inscribed in the UNESCO Representative List, along with the communities and their local cultural centres, which represent them (including also survakar associations ${ }^{15}$ ), the different institutions in Pernik District, such as the Regional Museum of History - Pernik, the Regional ExpertConsulting and Information Centre - Pernik, the 'Culture' Department at the Pernik Municipality and others, played an important roles too.

In 2016, a non-governmental organization was established in the town of Pernik with the aim of working in the sphere of safeguarding the region's local cultural heritage (material and intangible) with specific reference to the Surva element. Some of its initiators had participated as experts in the town's cultural institutions in past decades and had taken an active role in preparing the two nominations of the custom for the national and world lists. They were also among the masterminds in realizing the initiative to create a non-profit association. The main work of the association was directed to having the Surova feast inscribed in the UNESCO Representative List. The goal is to continue joint activities with local communities to maintain the vitality of the element and support its dissemination, as well as, if necessary, taking safeguarding measures.

In this way, a 'Local Heritage' Non-profit Association was registered in Pernik in 2016. ${ }^{16}$ The initiative started at the local level, and all of its founders were one way or another concerned with the safeguarding of the masquerade tradition in the region. Once the NGO was registered, its initial significant activities were naturally related to that element of the intangible cultural heritage. One of the Association's basic tasks is to continue the systematic work of collecting information about the custom in various regional villages and of recording it in its natural milieu, thus creating an archive consisting of different types of documents (audio, video, photos and text materials). 
At the beginning of 2019, the 'Local Heritage' Association adopted an initiative supported by the Regional Centre for the Safeguarding of the Intangible Cultural Heritage in South-Eastern Europe under the auspices of UNESCO. Workshops were organized to manufacture survakar masks on the eve of the feast of Surva, the aim being to demonstrate the method of mask manufacture both to the children and young people in a village with a living masquerade tradition and among those from an urban environment as well. A bearer of the masquerade tradition in the Pernik Region demonstrated the manufacturing technology. The workshops were carried out in the course of several days in 'St. Luke' National Secondary School of Applied Arts in Sofia and in the 'Ivan Vazov' Primary School in the village of Izvor, Radomir Region, Pernik District (Fig. 8). The manufactured masks were presented at the exhibition called 'An Encounter with Surova' in the town of Pernik (Fig. 9).

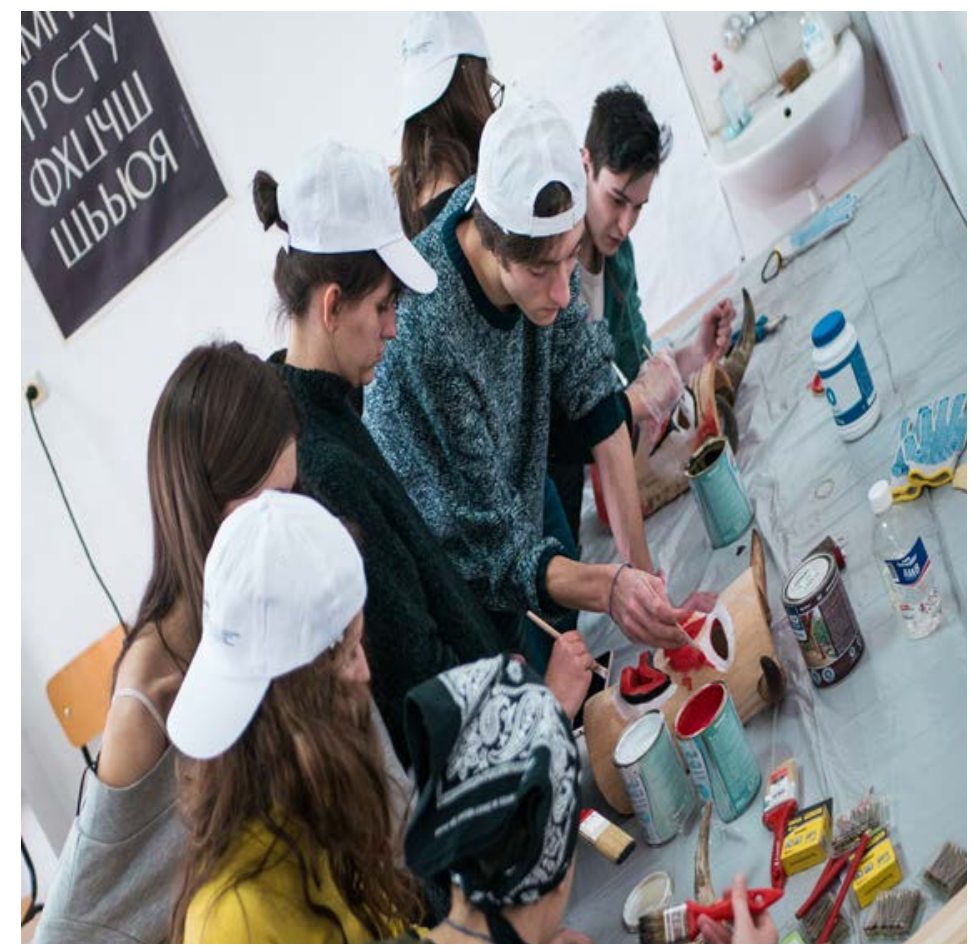

Figure 8. Workshop for survakar masks. Fhoto: Aleksandar Atanasov, 2019. (Archive: 'Local Heritage' Association). 


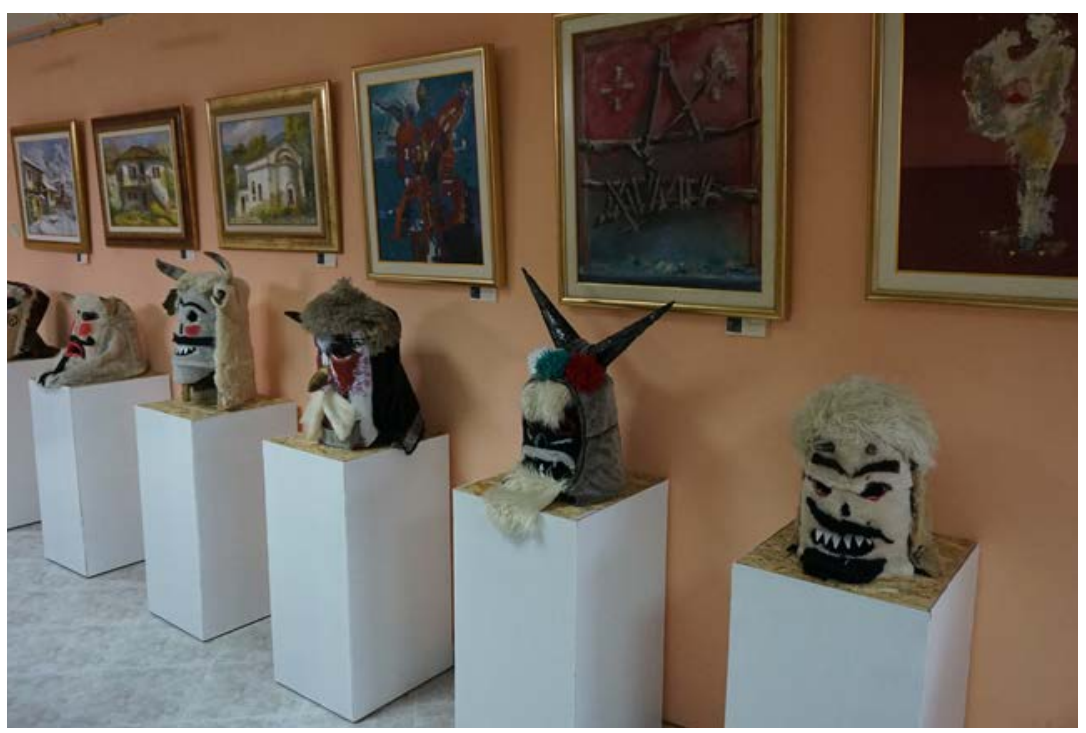

Figure 9. Exhibition of survakar masks. Fhoto: Milena Lyubenova, 2019. (Archive: 'Local Heritage' Association).

In 2018, the 'Local Heritage' Association started implementing a project supported by the 'Culture' National Fund entitled 'Popularizing the Custom of Surva by Means of an Interactive Web Page.' The objective of the project was to introduce one of the significant elements of the intangible cultural heritage in Pernik region, namely the feast Surva to the internet. This would improve access to information about the custom among a wide circle of users in the virtual space by creating a multimedia product representing all the survakar groups in the region on a common platform, which would provide textual information (in Bulgarian and in English), along with photo and video materials. The aim was to widen the possible visibility of the element nationally and internationally by introducing the information in a synthesised and popular form.

The main activities envisaged in the project were investigations in archives, field research, and establishing and enriching the interactive site. Interviews were conducted, observations were carried out in the settlements that had preserved the tradition, and various audio-visual materials were collected (photos, audio and video-recordings). Archive documents were examined as well (interviews, photos and video recordings) from the Regional Museum of 
History - Pernik, the State Archives - Pernik, and the Institute of Ethnology and Folklore Studies with Ethnographic Museum - Bulgarian Academy of Sciences. The collected information was processed, texts were prepared with translations in English, and the visual materials were selected.

On the website ${ }^{17}$ one can find information about the Surva custom in Pernik Region, both the masquerade's traditional characteristics and its contemporary manifestations (Fig. 10). The main characters that are typical of the winter games with masks in the region are outlined. Also represented are all the survakar groups in Pernik area, their arrangement following the territorial divisions of their villages. The masquerade tradition is still a living practice in five municipalities of Pernik District: Breznik, Zemen, Kovachevtsi, Pernik and Radomir.

Every survakar group is introduced with a text and photo and video materials. The texts include information taken from interviews conducted in the villages and from archive documents. The interviews were conducted with

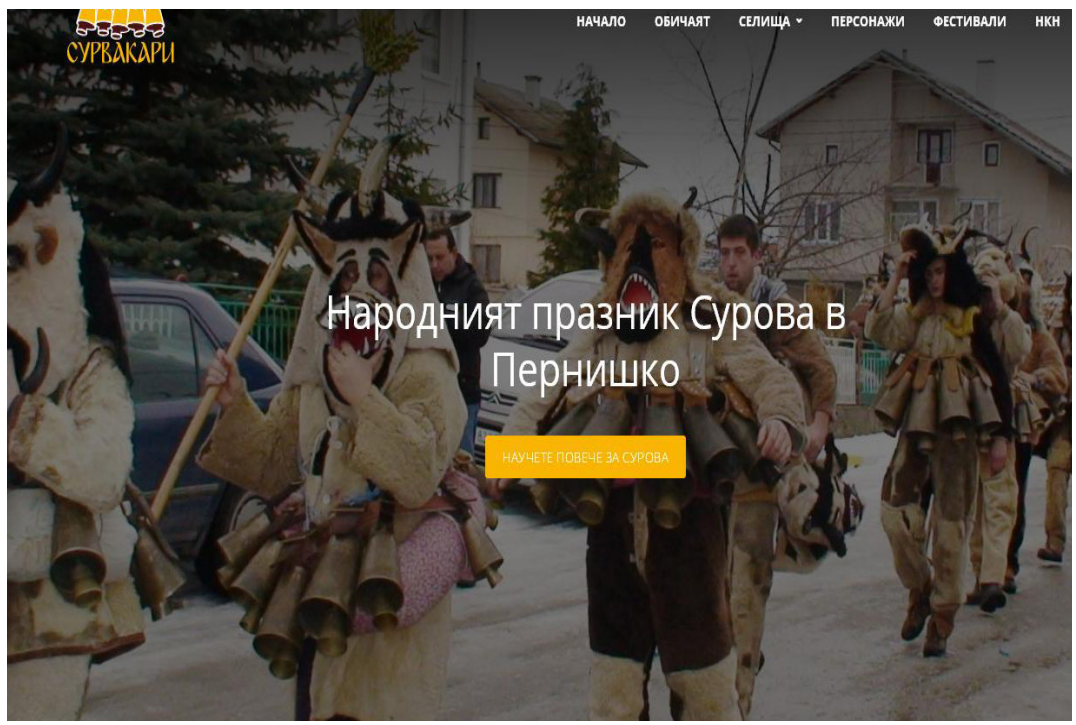

Figure 10. The website of the Survakar groups in Pernik region (https://survakari.com/). 
different generations of participants in the survakar groups and with survakars with definite roles in the masquerade: bolyubashiya (leader of the group), 'bride', 'bridegroom', 'priest', etc.; from hosts (members of the local community who welcome the masked characters into their homes); and from representatives of the settlements who have administrative and staff functions and at the same time take part in the life of the survakar groups. ${ }^{18}$

The visual materials represent the masquerade in the settlements with archive photos and video recordings. Some of the photos convey an idea of how Surva was celebrated some decades ago. The masquerade participants themselves submitted them for the site, but some of the old photos were also selected from the State Archives in Pernik. The video materials were recorded more recently and show the contemporary state of the survakar games in the region. Information about the participation of the masquerade groups in various festivals in the country and abroad is also given on the site. A separate section presents the work carried out in Bulgaria on fulfilling the requirements of Convention 2003, as well as the involvement of the Surva fest in the National System 'Living Human Treasures - Bulgaria' in 2012, and inscription of the element in the respective Lists of the Intangible Cultural Heritage - the National one and that of Humanity.

Among the important aims of the project is to enrich the site by building up a body of different types of documents that record the past and the present state of the Surva feast in Pernik Region, namely audio and video recordings, photos and written documents. As a result, an archive collection will be built up that can be successfully used in the future for purposes of both investigation and popularization. On the other hand, it is important to continue the field research and to maintain the site, enriching it with new information. Building the webpage plays a positive role in accumulating information, while representatives from different survakar groups and from village communities continue to provide additional data, mainly photos and facts about the masquerade groups. Besides widening the visibility of this cultural tradition that is so significant in the Pernik region, the site also aims to encourage feedback with the communities, which should continue to have an active role in safeguarding their local intangible cultural heritage in the future as well. They should therefore transmit the tradition to the following generations and should get involved in activities for its preservation and popularization through further investigations and recording activities. 
Nowadays, local activities for safeguarding this intangible cultural heritage are in accordance with the implementation of Convention 2003. Undoubtedly, the inscription of the Surova fest in the UNESCO Representative List has increased the self-confidence of the bearers of the masquerade tradition in the Pernik region and engaged certain actors from the local community who saw prospects for new activities and initiatives related to safeguarding and promoting the element. However, the involvement of the local community, as well as the interaction between the bearers, experts and institutions that conduct the official cultural policies of the state was a fact well before the ratification of Convention 2003 and the inscription of the element in the Representative list. Safeguarding these masquerade games as a living practice at the present day is the next step in a process that began in the middle of the twentieth century. The community continues to have an important role in safeguarding this local cultural practice. In implementing measures for protection of the element, close interaction between bearers and experts and institutional support occurs within the local community.

\section{Conclusion}

The processes related to safeguarding the intangible cultural heritage comprise the whole range of activities, from maintaining the vitality of the elements of local culture via their investigation and recording to the permanent preservation of traditional knowledge of the practice in archive collections, thus creating opportunities for widening its visibility. In practice, the local communities take part in all stages of the safeguarding: maintaining the vitality of traditional knowledge, skills and practices, ensuring their transmission to the following generations, collecting and recording the heritage (audio, photo and video documentation), preserving the collected information in archives and popularizing the local cultural traditions (Lyubenova 2017: 132-9).

One significant factor in activities to preserve the intangible cultural heritage is the cooperation and dialogue between the communities and the experts locally and nationally. Also quite important is the interaction between local cultural centres, national institutions and non-governmental organizations working to preserve this type of heritage (Lyubenova 2021: 82-196). The joint efforts and the mutual confidence between the different actors involved in the processes of safeguarding intangible cultural heritage may achieve good results when there is a dialogue and mutual understanding and when their work is 
synchronized. In the circumstances of a globalizing world and of the mass migration of people in recent decades, those endeavours are and will continue to be an important factor in safeguarding the already preserved and still living elements of the traditional culture of local communities and in transmitting them to the generations to come.

\section{Acknowledgements}

This text has been prepared within the framework of the project 'Safeguarding the Cultural Heritage - Analyses, Documents, Practices', which is financially supported by the Scientific Research Fund, agreement No. DN 09/17, to which I convey my thanks.

\section{Notes}

${ }^{1}$ https://ich.unesco.org/en/convention (11.11.2021).

${ }^{2}$ Masquerade games are a living practice today in many regions of Bulgaria, with a wide local variety of masquerade practices in terms of local name, geographical and temporal parameters. A number of researchers make typologies according to the respective features (Arnaudov 1972; Petrov 1972; Cherkezova 1960, etc.). The most common classification scheme of masquerade practices can be summarized in two terms: survakar and kuker type of masquerade (Cherkezova 1960; Petrov 1972; Stamenova 1982). The Survakar type is associated with the celebration of the New Year (the old orthodox style), and the Kuker's type - during the time of Shrovetide (see also BoyadzhievaPeeva 2020: 109-116).

${ }^{3}$ On 9 September 1944 Bulgaria established a totalitarian form of government under the Communist Party. As a result, major political, economic and social changes occurred in society.

${ }^{4}$ Interviews providing information about these events are preserved in the Scientific Archive of the Regional Historical Museum at Pernik.

${ }^{5}$ At the end of nineteenth and the beginning of the twentieth century, Pernik was a significant mining centre in Bulgaria, and after the second half of the twentieth century, it experienced some large-scale industrial activity in the spheres of metallurgy and machine-building.

${ }^{6}$ For more on the masquerade tradition and culture policies in this period, see Bokova 2010. 
${ }^{7}$ In 1995 the International Federation of Carnival Cities accepted the town of Pernik as its full member. In June, 2009 Pernik was proclaimed as the European capital of Surva 's and Mumers. More information about the festival can be found at: http://en.surva.org/ (11 11. 2021).

${ }^{8}$ https://www.treasuresbulgaria.com/main.php (11.11.2021).

${ }^{9}$ https://bulgariaich.com/index.php?act=content\&rec=12 (11.11.2021).

${ }^{10}$ Chitalishte (community centres) are specific to Bulgarian civil and cultural organizations, which have a special place in modern processes of safeguarding the intangible cultural heritage of local communities. For more on this topic, see Nenova 2016.

11 https://ich.unesco.org/en/RL/surova-folk-feast-in-pernik-region00968?fbclid=IwAR34-TSU_rEObfmSBpcP5WAPBIdW9hlhX_flItuDUyDjVgHJUPQoGlim4o (11.11.2021).

${ }^{12}$ https://ich.unesco.org/en/directives (11.11.2021).

${ }^{13}$ https://ich.unesco.org/en/ngo-centers-and-research-00329\#ngos-and-the-2003-convention (11.11.2021).

${ }^{14}$ More on the role of the non-governmental organizations in safeguarding of the intangible cultural heritage see can be found in Kwang Hee Kim 2014: 53-65; Babić 2015: 27-34; Lancere and Vaivade 2017: 100-111; and Sousa and Refólio 2018.

${ }^{15}$ In the settlements with living masquerade tradition, besides the chitalishta [culture centres], some associations function, which are registered as legal entities, the so-called survakar associations, or others, registered with a wider sphere of activities, connected to safeguarding of the local cultural heritage.

${ }^{16}$ https://lokalnonasledstvo.com/ (11.02.2021).

${ }^{17}$ For more information about the website, see https://survakari.com/ (11.11.2021).

${ }^{18}$ The author of this paper also participated in the interviews.

\section{References}

Arnaudov, Mikhail 1972. Kukeri i Rusalii [Kukers and Rusalii]. In: Studii varhu bulgarskite obredi i legendi [Study of the Bulgarians Rituals and Legends]. Vol. 2. Sofia: Publishing House of Bulgarian Academy of Sciences, pp. 63-112.

Babić, Darko 2015. Social Responsible Heritage Management: Empowering Citizens to Act as Heritage Managers. In: Procedia - Social and Behavioral Sciences, Vol. 188, pp. 27-34.

Bokova, Irena 2010. Maskaradat - kulturno nasledstvo i lokalni praktiki [The Masquerade: Local Heritage and Cultural Practices]. In: Godishnik na department 
'Antorpologiya' [Yearbook of the Department of Anthropology] Vol. 4. Sofia: NBU - http://ebox.nbu.bg/apl2010/index.php?p=12.

Boyadzhieva-Peeva, Emiliya 2020. Nematerialno kulturno nasledstvo - zhiva praktika $i$ sistemi za vpisvane na elementi: Primerat na maskata [Intangible Cultural Heritage - Living Practice and Systems for Inscription of Elements: The Example of the Mask]. Dissertation for awarding the educational and scientific degree 'Doctor of Philosophy'. Sofia: Institute of Ethnology and Folklore Studies with Ethnographic Museum.

Cherkezova, Marina 1960. Tipologiya i razprostranenie na sirviskarski i kukerski maski, obleklo i rekvizit v Bulgaria [Typology and Distribution of Sirvakars and Kukers Masks, Ritual Dress and Props in Bulgaria]. In: Ezikovedsko-etnografski izsledvaniya v pamet na Stoyan Romanski [Linguistic and Ethnographic Studies in Memory of Stoyan Romanski]. Ed. Vladimir Georgiev et al. Vol. VIII. Sofia: Publishing House of Bulgarian Academy of Sciences, pp. 189-191.

Georgiev, Milcho 2017. Mezhdunaroden festival na maskaradnite igri 'Surva'. Letopis. [International Festival of Masquerade Games 'Surva'. Pernik: Izdatelstvo 'Dvorets na kulturata'

Ivanova, Miglena 2016. Collaboration, Dialogue, Negotiation and Consultation with the Communities in the Process of the Implementation of Safeguarding Policies in Bulgaria. [Satrudnichestvo, dialog, pregovori i konsultatsii s obshnostite pri osashtestviyavane na kulturni politiki za opazvane na nematerialnoto kulturno nasledstvo] - In: The Contribution of UNESCO Member States of South-Eastern Europe to the Implementation of the Convention for the Safeguarding of the Intangible Cultural Heritage. A Jubilee Edition Dedicated to the 70-th Anniversary of UNESCO. Sofia: Regional Centre for the Safeguarding of Intangible Cultural Heritage in South-Eastern Europe under the auspices of UNESCO, pp. 73-82. Kraev, Georg 2003. Maska i bulo [Mask and Veil]. Sofia: Iztok - Zapad Press.

Kwang Hee Kim 2014. Safeguarding Intangible Cultural Heritage and the role of NGOs. In: Towards Efficient Roles of NGOs for Safeguarding ICH in the Asia-Pacific Region, pp. 53-65. - http://www.ichcap.org/eng/ek/sub8/pdf_file/07/06.\%20 Chapter\%201_Safeguarding\%20Intangible\%20Cultural\%20Heritage\%20 and\%20the\%20Role\%20of\%20NGOs.pdf.

Lancere, Gita, and Anita Vaivade 2017. Safeguarding Intangible Cultural Heritage in Latvia: Insights into the Contribution of NGOs. In: Schreiber, H. (ed.). Intangible Cultural Heritage. Safeguarding Experiences in Central and Eastern European Countries and China. 10th Anniversary of the Entry into Force of the 2003 UNESCO Convention through the Prism of Sustainable Development. Warsaw: National Heritage Board of Poland, pp. 100-111. 
Lyubenova, Milena 2017. Sahranenie na nematerialnoto kulturno nasledstvo: ot zhivata praktika do arhiva [Safeguarding of Intangible Cultural Heritage: From the Living Pracitce to the Arhive]. - In: Opazvane na kulturnoto nasledstvo. Idei $i$ praktiki. Po sluchai 60 godini ot prisaedinyavaneto na Bulgaria kam UNESCO [Safeguarding of Cultural Heritage. Ideas and Practices. Dedicated to the 60th Anniversary of the Joining of Bulgaria to UNESCO. Sofia: Prof. Marin Drinov Publishing House of Bulgarian Academy of Sciences, pp. 132-139.

Lyubenova, Milena 2021. Obshtnosti i eksperti v opazvaneto na nematerialnoto kulturno nasledstvo - primerat na Surva v Pernishko [Communities and Experts in Safeguarding Intangible Cultural Heritage: the Example of Surva in Pernik Region]. In: Nematerialno kulturno nasledstvo. Aktualni problemi. [Intangible Cultural Heritage. Current Problems]. Sofia: Prof. Marin Drinov Publishing House of Bulgarian Academy of Sciences, pp. 182-196.

Manova, Tsvetana 1977. Zhenitbeni belezi na obichaya survakari v Zapadana Bulgaria [Marriage Signs of the Survakari Custom in Western Bulgaria]. Vekove, 4, pp. 24-30.

Manova, Tsvetana 2012. Maskaradni igri v Sredna Zapadna Bulgaria prez vtorata polovina na 20 vek [Masquerade Games in Middle Western Bulgaria in the second half of the 20th century. In: Mezhdunaroden festival na maskaradnite igri 'Surva' - Pernik. Bibliografski ukazatel [International Festival of Masquerade Games 'Surva' - Pernik. Bibliography. Dimitrina Chalakova Ed. Pernik: Izdatelstvo 'Dvorets na kulturata', pp. 7-40.

Nalbantyan-Hacheryan, Silva 2018. Nematerialno kulturno nasledstvo - politiki i praktiki za negovoto opazvane [Intangible Cultutal Heritage: Policies and Practicies for its Safeguarding]. Dissertation for the academic degree of 'Doctor of Science.' Sofia: Institute of Ethnology and Folklore Studies with Ethnographic Museum. Nalbantyan-Hacheryan, Silva 2019. Nematerialno kulturno nasledstvo-politiki i praktiki za negovoto opazvane [Intangible Cultural Heritage: Policies and Practises for its Safeguarding]. Sofia: Prof. Marin Drinov Publishing House of Bulgarian Academy of Sciences.

Nenova, Stela 2016. Bulgarskite Chitalishta i sahranenito na folklora [The Bulgarian Chitalishta and Safeguarding of the Folklore]. Dissertation for awarding the educational and academic degree of 'Doctor of Philosophy'. Sofia: Institute of Ethnology and Folklore Studies with Ethnographic Museum.

Petrov, Petar 1972. Kukeri i Survakari [Kukers and survakars]. In: Izvestiya na bulgarskoto istorichesko druzhestvo [Proceedings of the Bulgarian Historical Society], № 28, pp. 267-280. 
Sousa, Filomena (Collaboration: Vera Refólio) 2018. The Participation in the Safeguarding of the Intangible Cultural Heritage. The role of Communities, Groups and Individuals. Alenquer: Memória Imaterial CRL.

Stamenova, Zhivka 1982. Kukeri i Survakari [Kukers and Survakars]. Sofia: Darzhavno izdatelstvo 'Septemvri'.

Stanoeva, Iva 2016. Local Actors and Practices of Safeguarding of the Intangible Cultural Heritage of Bulgaria. [Lokalni aktyori I praktiki v opazvaneto na nematerialnoto kulturno nasledstvo na Bulgarias]. In: The Contribution of UNESCO Member States of South-Eastern Europe to the Implementation of the Convention for the Safeguarding of the Intangible Cultural Heritage. A Jubilee Edition Dedicated to the 70-th Anniversary of UNESCO. Sofia: Regional Centre for the Safeguarding of Intangible Cultural Heritage in South-Eastern Europe under the auspices of UNESCO, pp. 179-191.

Milena Lyubenova, PhD, Assistant Professor at the Institute of Ethnology and Folklore Studies with Ethnographic Museum, Bulgarian Academy of Sciences (IEFSEM - BAS). She is Head of the National Center for Intangible Cultural Heritage at IEFSEM - BAS. Her major interests are in the field of Safeguarding of Intangible Cultural Heritage, Local History and Culture, Archival Sciences. 